\title{
Kinetic are crucial when targeting copper ions to fight Alzheimer's disease: an illustration with azamacrocyclic ligands
}

Amandine Conte-Daban, ${ }^{[a, b]}$ Maryline Beyler, ${ }^{[c]}$ Raphaël Tripier ${ }^{[c]}$ and Christelle Hureau ${ }^{*[a, b]}$

[a] Amandine Conte-Daban, Christelle Hureau

CNRS, LCC (Laboratoire de Chimie de Coordination)

205 route de Narbonne, BP 4409931077 Toulouse Cedex 4, France

E-mail: christelle.hureau@lcc-toulouse.fr

[b] Amandine Conte-Daban, Christelle Hureau

University of Toulouse

UPS, INPT, 31077 Toulouse Cedex 4, France

[c] Maryline Beyler, Raphaël Tripier

Université de Bretagne Occidentale

UMR-CNRS 6521 CEMCA, IBSAM

UFR des Sciences et Techniques, 6 avenue Victor le Gorgeu, C.S. 93837, 29238 BREST Cedex 3, France

Abstract: Targeting copper ions to either remove or redistribute them is currently viewed as a possible therapeutic strategy in the context of Alzheimer's disease (AD). Thermodynamic parameters, as for instance the copper(II) affinity of the drug candidate or the copper(II) over zinc(II) selectivity, are considered in the design of the drug candidate. In contrast, kinetic ones have been overlooked despite their probable high importance. In the present article, we use a series of azamacrocyclic ligands to demonstrate that kinetic issues must be taken into account when designing copper-targeting drug candidates in the context of $A D$. 


\section{Introduction}

$A D$ is the most common neurodegenerative disorder characterized by the formation of extracellular senile plaques. ${ }^{[1]}$ They are found in $\mathrm{AD}$ brains and contain high levels of $\mathrm{Cu}^{2+}$ and $\mathrm{Zn}^{2+}$ ions embedded with aggregates of the amyloid- $\beta$ (A $\beta$ ) peptide. ${ }^{[2]}$ Aggregates of $A \beta$ can be of various size and morphologies with distinct cell toxicity. ${ }^{[3]}$ While metal ions can effect aggregation pathways and final species, neither the mechanism nor the resulting type of aggregates is clear. Cu ions are essential and play key biological roles, ${ }^{[4]}$ but due to their ill-controlled redox ability they are harmful in AD. ${ }^{[5]}$ Actually, A $\beta$-bound $\mathrm{Cu}$ ions in the presence of a reductant such as ascorbate (Asc) present at 200-400 $\mu \mathrm{M}$ in the synaptic cleft and of dioxygen, produce Reactive Oxygen Species (ROS) that participate in the oxidative stress observed in $A D$ and damage neighboring biomolecules. ${ }^{[5 b]}$ This is one of the main reason why molecules targeting copper ions, mainly $\mathrm{Cu}^{2+}$, have been developed as drug candidates within the context of AD. Such ligands can remove $\mathrm{Cu}^{2+}$ from $\mathrm{A} \beta$ (chelator) and optionally redistribute it intracellularly (metallophore) and many of them have been reported in the last years. ${ }^{[6]}$ They fulfill several requirements, including having a higher affinity for $\mathrm{Cu}^{2+}$ than the $\mathrm{A} \beta$ peptide, the ability to redox silence the $\mathrm{Cu}^{2+}$ ion and a very high $\mathrm{Cu}^{2+}$ over $\mathrm{Zn}^{2+}$ selectivity. ${ }^{[7]}$ However, because the synaptic cleft where the Cu-A $\mathrm{C}$ interaction occurs is proposed to be a quite reducing environment, ${ }^{[8]} \mathrm{Cu}^{2+}$ might not be the most appropriate redox state of copper to target. Thus, a first possible strategy is to target $\mathrm{Cu}^{+},{ }^{[9]}$ or both redox states. ${ }^{[10]} \mathrm{A}$ second one is to design $\mathrm{Cu}^{2+}$ drug candidates that are able to remove $\mathrm{Cu}^{2+}$ "fast enough" from the A $\beta$ peptide. Indeed during ROS production the copper ion switches between the $+\mathrm{I}$ and $+\mathrm{Il}$ redox state; hence an efficient $\mathrm{Cu}^{2+}$ ligand should remove the transient $\mathrm{Cu}^{2+}$ from the $\mathrm{A} \beta$ peptide and redox-silent it faster than Asc can reduce it (Scheme 1).

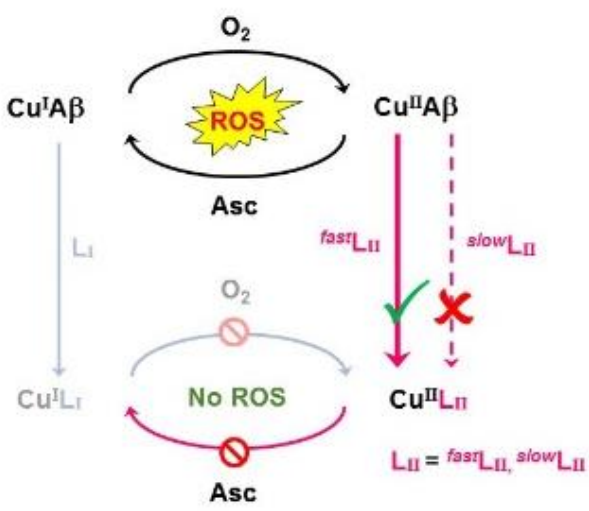

Scheme 1. Two approaches to stop $\mathrm{Cu}-\mathrm{A} \beta$ ROS production. On the one hand, $\mathrm{Cu}^{\mathrm{I}}$ is targeted and the complex $\mathrm{Cu}^{\mathrm{I}} \mathrm{L}_{\mathrm{I}}$ is inert toward $\mathrm{O}_{2}$ oxidation (shaded part of the scheme). On the other hand, $\mathrm{Cu}^{\mathrm{II}}$ is targeted and the complex $\mathrm{Cu}^{\mathrm{II}} \mathrm{L}_{\mathrm{II}}$ is inert toward Asc reduction. Two possibilities occur: (i) if $\mathrm{L}_{\text {II }}$ is able to remove the $\mathrm{Cu}^{2+}$ from $A \beta$ faster (bold solid line, $L_{I I}={ }^{\text {fast }} L_{I I}$ ) than Asc reduces it, then it is efficient $(\checkmark)$; (ii) if not (dashed line, $\left.L_{I I}={ }^{\text {slow }} L_{I I}\right)$ then it is inefficient $(x)$ although it could be able to remove $\mathrm{Cu}^{2+}$ from $\mathrm{A} \beta$ on longer time scales in absence of Asc. $\checkmark$ and $x$ refer to the notation used in Table 1.

Tetraazamacrocycles are ligands that fulfill the thermodynamic criteria stated above and are well known for the kinetic inertness and the thermodynamic stability of the complexes counterparts. In particular, 1,4,7,10-tetraazacyclododecane (cyclen) and 1,4,8,11tetrazacyclotetradecane (cyclam) have been previously tested in the AD context with mitigating results. ${ }^{[1]}$ They are also the scaffolds of many chelators used for radiopharmaceutical purposes that bind ${ }^{64 / 67} \mathrm{Cu}^{2+}$, respectively for positron emission tomography and/or therapy and $\mathrm{Gd}^{3+}$ for magnetic resonance imaging, for instance. ${ }^{[12]}$ As a general trend, $\mathrm{Cu}^{2+}$ complexation with unsubstituted tetraazamacrocycles is quite slow and pending arms are added to improve the rate of $\mathrm{Cu}^{2+}$ complexation, ${ }^{[13]}$ as it was also observed with other cations. ${ }^{[14]}$ Inspired by these works, we report here the use of two families of tetraazamacrocycles based on the cyclen or cyclam scaffold as potential $\mathrm{Cu}^{2+}$ chelators against $\mathrm{AD}$ and illustrate the importance of kinetic issues in the removal of $\mathrm{Cu}^{2+}$ from the $\mathrm{A} \beta$ peptide $^{\ddagger}$ and subsequent ROS arrest.

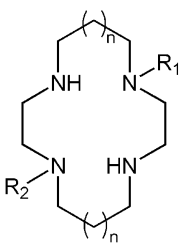

cyclen: $n=0, R_{1}=R_{2}=H$ do1pa: $n=0, R_{1}=H_{1}, R_{2}=$ methylpicolinate do2pa: $n=0, R_{1}=R_{2}=$ methylpicolinate cyclam: $n=1, R_{1}=R_{2}=H$
te1pa $n=1, R_{1}=H$ te2pa: $n=0, R_{1}=R_{2}=$ methylpicolinat<smiles>CCCc1cccc(C(=O)O)n1</smiles>

Scheme 2. Representation of the six different azaligands studied.

\section{Results and Discussion}

Scheme 2 shows the structure of the six ligands used in the present study. In addition to the non-functionalized cyclen and cyclam ligands, four macrocycles based on cyclen and cyclam ligands and bearing one (do1pa and te1pa, respectively) or two (do2pa and te2pa, respectively) methylpicolinate pendant arms were studied. Te2pa is new and as for its three analogues, has been obtained following the regiospecific $\mathrm{N}$-functionalization of the macrocycle via the bisaminal chemistry (synthetic scheme S1). A view of the structure of the $\mathrm{Cu}^{2+}$ corresponding complex is shown in Figure 1, while bond distances and angles of the metal coordination 
environment are given in the caption (see also Tables S1-S2). The central $\mathrm{Cu}^{2+}$ cation is six-coordinated in a highly elongated octahedral geometry, with the four nitrogen atoms of the macrocycle in the equatorial plane and the two nitrogen atoms of the picolinate arms at the apical positions. The Cu-NH (Cu- $\left.\mathrm{N}_{2}\right)$ bond are shorter than the Cu- $\mathrm{N}_{1}$ bond (1.9974(13) versus 2.0462(13) $\AA$ ) whereas the apical Cu- $\mathrm{N}_{3}$ bonds are much longer $(2.7910(16) \AA)$ due to the Jahn-Teller distortion. The carboxylate functions do not participate to the coordination of the metal center as observed for te1pa. ${ }^{[15]}$ This six-coordinated $\mathrm{Cu}^{2+}$ complex adopts the usually observed trans-III configuration ( $R, R, S, S$ conformation). The thermodynamic protonation constants of te2pa and its stability constants with $\mathrm{Cu}^{2+}$ were determined in $0.10 \mathrm{M} \mathrm{KNO}_{3}$ at $25^{\circ} \mathrm{C}$ using potentiometric titrations.

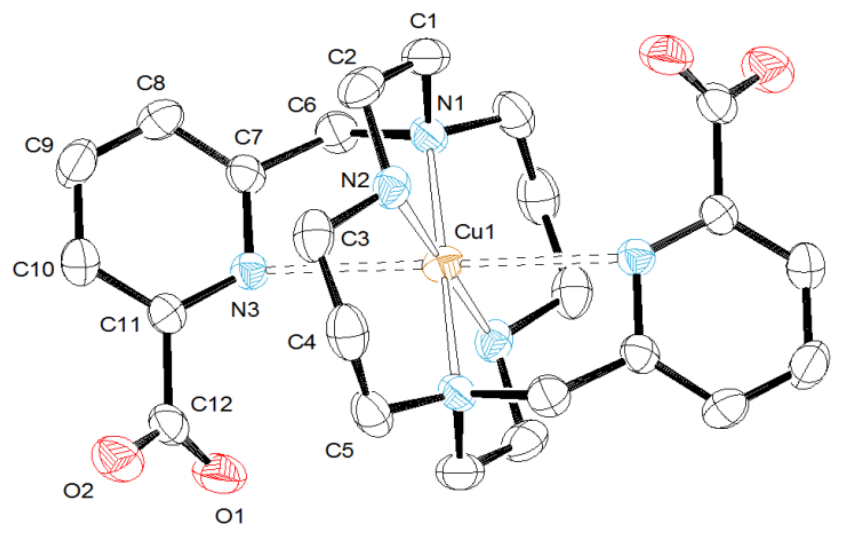

Figure 1. X-ray crystal structure of $\mathrm{Cu}^{2+}$-te2pa with atom labelling; hydrogen atoms and water molecules are omitted for simplicity. The ORTEP plots is drawn at the $30 \%$ probability level. Cu-N(1)=2.0604(15), Cu-N(2)=1.9906(15), Cu-N(3)=2.7910(16), N(1)-Cu-N(2)=86.61(6), N(1)-Cu-N(2)=93.39(6), N(1)-Cu-N(3)=75.81(5), $\mathrm{N}(2)-\mathrm{Cu}-\mathrm{N}(3)=87.90(6), \mathrm{N}(3)-\mathrm{Cu}-\mathrm{N}(1)=104.19$. Symmetry transformations used to generate equivalent atoms: $\# 1-x+1,-\mathrm{y}+1,-\mathrm{z}+1$.

The stepwise constants $(\log (\mathrm{K}))$ and the overall constants $(\log (\beta))$ are collected in Table $S 3$, while the speciation diagrams are showed in Figures S1-S2. The conditional affinity constant (corresponding to the absolute affinity constant at a given $\mathrm{pH}$ ) has been calculated from the $\log (\mathrm{K})$ and $\log (\beta)$ values and equals $10^{14.9}$ at $\mathrm{pH} 7.1$, a weaker value compared to affinity constants of the other five ligands under study (Table 1). ${ }^{[15-16]}$ XANES and EPR signatures of the six $\mathrm{Cu}^{2+}-\mathrm{L}(\mathrm{L}$ is any of the ligand studied) complexes in frozen solution are shown in Figures S3-S4 and corresponding EPR parameters are listed in Table 1. EPR signatures and parameters are consistent with an elongated octahedral geometry and a $4 \mathrm{~N}$ binding set in the equatorial plane. ${ }^{[17]}$ XANES fingerprints of $\mathrm{Cu}^{2+}$-te2pa is reminiscent of those of the parent $\mathrm{Cu}^{2+}$-cyclam complex in line with the X-ray structure (Figure 1) that indicates an extremely long apical distance.

The cyclic voltammograms of the six complexes (Figure S5) indicate the possibility of reduction of the $\mathrm{Cu}^{2+}$ ion but at very low potentials (below $-0.5 \mathrm{~V}$ versus SCE). As a general trend, addition of methylpicolinate arm(s) makes the reduction easier, i.e. the reduction occurs at higher potential (Table 1). Given the potential values of the cathodic process observed for all complexes, reduction by Asc is thermodynamically disfavored. ${ }^{[0]}$

Table 1. Thermodynamic, spectroscopic and electrochemical characteristics of the six studied $\mathrm{Cu}^{2+}$ complexes.

\begin{tabular}{|c|c|c|c|c|c|c|}
\hline & $\mathrm{Cu}^{2+}$-cyclen & $\mathrm{Cu}^{2+}$-do1pa & $\mathrm{Cu}^{2+}-\mathrm{do} 2 \mathrm{pa}$ & $\mathrm{Cu}^{2+}$-cyclam & $\mathrm{Cu}^{2+}$-te1pa & $\mathrm{Cu}^{2+}-\mathrm{te} 2 \mathrm{pa}$ \\
\hline Coordination & 4Neq 1Oap & $5 \mathrm{~N} 10$ & N.D.[a] & $4 \mathrm{Neq}$ & $4 \mathrm{Neq} 1 \mathrm{Nap}$ & $4 \mathrm{Neq}$ (2 Nap) \\
\hline $\log K_{a}^{C u} \mathrm{pH} 7.1$ & $17.4-18.8$ & 18.5 & 17.4 & $19.9-20.8$ & 18.0 & 14.9 \\
\hline refs. & [18] & {$[15]$} & {$[16]$} & [19] & {$[15]$} & This work \\
\hline$g_{/ /}$ & $2.20 \pm 0.01$ & $2.23 \pm 0.01$ & $2.23 \pm 0.01$ & $2.18 \pm 0.01$ & $2.19 \pm 0.01$ & $2.18 \pm 0.01$ \\
\hline $\mathrm{A}_{/ /}\left({ }^{65} \mathrm{Cu}\right)\left(10^{-4} \mathrm{~cm}^{-1}\right)$ & $202 \pm 5$ & $187 \pm 5$ & $181 \pm 5$ & $224 \pm 5$ & $211 \pm 5$ & $217 \pm 5$ \\
\hline $\mathrm{E}_{\mathrm{pc}}$ (V vs. SCE) & -0.85 & -0.82 & -0.67 & -0.98 & -0.88 & -0.76 \\
\hline Reversibility ${ }^{[a]}$ & Irrev. & Rev. & Rev. & Irrev. & Rev. & Irrev. \\
\hline $\begin{array}{l}\text { Incubation } \\
\mathrm{Cu} \text { or } \mathrm{Cu}-\mathrm{A} \beta\end{array}$ & $\sqrt{[c]}$ & $\checkmark$ & $\checkmark$ & $\checkmark$ & $\checkmark$ & $\checkmark$ \\
\hline No incubation & & & & & & \\
\hline $\mathrm{Cu}$ & $\sim$ & $\checkmark$ & $\checkmark$ & $x$ & $\checkmark$ & $\checkmark$ \\
\hline $\mathrm{Cu}-\mathrm{A} \beta$ & $x$ & $\checkmark$ & $\sim$ & $x$ & $\checkmark$ & $\checkmark$ \\
\hline
\end{tabular}

${ }^{[a]}$ Not determined, ${ }^{[b]}$ "Rev" indicates a electrochemically reversible or quasi-reversible process, "Irrev" indicates an electrochemically irreversible process, ${ }^{[c]}$

$\checkmark=$ total arrest, $x=$ no arrest, $\sim=$ incomplete arrest of ROS production. 
In line with the electrochemical measurements, once the $\mathrm{Cu}^{2+}$ complexes are formed with any of the six ligands, they can't be reduced by Asc as probed by the absence of Asc consumption monitored by UV-Vis (Figure S6, Panels A and B). Similarly, Asc consumption was not observed when $\mathrm{Cu}^{2+}-\mathrm{A} \beta 16$ complex was pre-incubated with the ligand (Figure 2, Panels $A$ and $B$ ). This is in line with the higher $\mathrm{Cu}^{2+}$ affinity values of the ligands compared to $A \beta$ (Table 1 ) and the resistance to Asc reduction of the resulting $\mathrm{Cu}^{2+}-\mathrm{L}$ complexes. Hence, the six macrocyclic ligands appear as good candidates for $\mathrm{Cu}^{2+}$ chelatotherapeutic purposes. In order to go further and challenge these ligands under more biologically relevant conditions, the Asc consumption assay was performed differently: $\mathrm{Cu}^{2+}$ (Figure S6, Panels $C$ and $D$ ) or $\mathrm{Cu}^{2+}-\mathrm{A} \beta$ (Figure 2, Panels $C$ and $D$ when $A \beta=A \beta 16$ and Figure S6, panels $E$ and $F$ when $A \beta=A \beta 40$ ) was first reacted with Asc and then the ligands were added. Such conditions better mimic the brain environment, which is at the same time rich in Asc and dioxygen. ${ }^{[20]}$
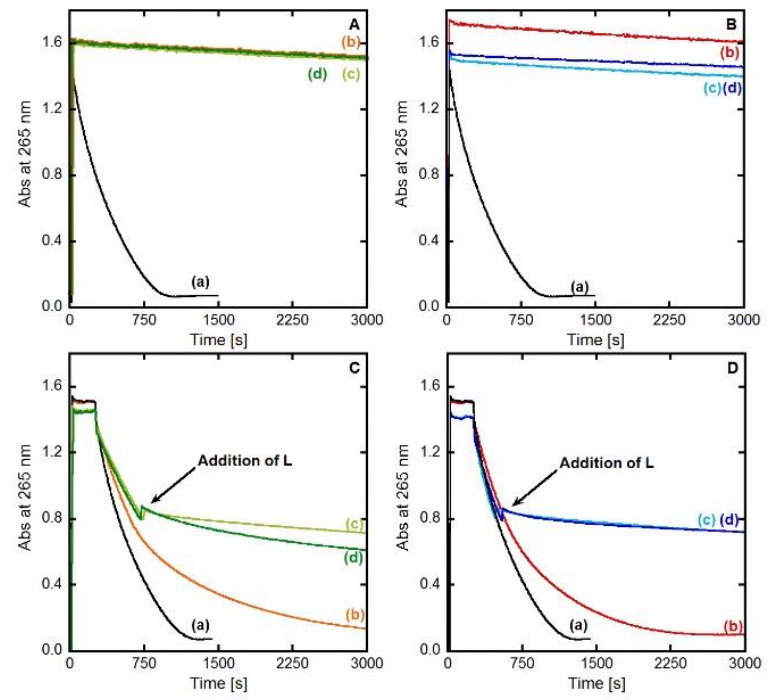

Figure 2. Kinetics of Asc consumption, followed by UV-visible spectroscopy at $265 \mathrm{~nm}$ with a background correction at $800 \mathrm{~nm}$. Panel $A$. (a) $A \beta 16+C \mathrm{u}^{2+}+\mathrm{Asc},(\mathrm{b})$ $\mathrm{A} \beta 16+\mathrm{Cu}^{2+}+$ cyclen+Asc, (c) $\mathrm{A} \beta 16+\mathrm{Cu}^{2+}+$ do1pa+Asc, (d) $\mathrm{A} \beta 16+\mathrm{Cu}^{2+}+$ do2pa+ Asc. Panel B. (a) $\mathrm{A} \beta 16+\mathrm{Cu}^{2+}+\mathrm{Asc}$, (b) $\mathrm{A} \beta 16+\mathrm{Cu}{ }^{2+}+\mathrm{cyclam}+\mathrm{Asc}$, (c) $\mathrm{A} \beta 16+\mathrm{Cu}^{2+}+\mathrm{te} 1 \mathrm{pa}+\mathrm{Asc}, \quad(\mathrm{d}) \mathrm{A} \beta 16+\mathrm{Cu}^{2+}+\mathrm{te} 2 \mathrm{pa}+\mathrm{Asc}$. Panel C. (a) $\mathrm{Asc}+\mathrm{A} \beta 16+\mathrm{Cu}^{2+}$, (b) $\mathrm{Asc}+\mathrm{A} \beta 16+C u^{2+}+\mathrm{cyclen}, \quad$ (c) $A s c+\mathrm{A} \beta 16+C u^{2+}+\mathrm{do} 1 \mathrm{pa}, \quad(\mathrm{d})$ $A s c+A \beta 16+C^{2+}+$ do2pa. Panel D. (a) $A s c+A \beta 16+\mathrm{Cu}^{2+}$, (b) $A s c+A \beta 16+\mathrm{Cu}^{2+}+\mathrm{cyclam}$, (c) $\mathrm{Asc}+\mathrm{A} \beta 16+\mathrm{Cu}^{2+}+$ te $1 \mathrm{pa}$, (d) $\mathrm{Asc}+\mathrm{A} \beta 16+\mathrm{Cu}^{2+}+\mathrm{te} 2 \mathrm{pa}$. $[\mathrm{L}]=[\mathrm{A} \beta 16]=12 \mu \mathrm{M}$, $\left[\mathrm{Cu}^{2+}\right]=10 \mu \mathrm{M},[\mathrm{Asc}]=10 \mu \mathrm{M},[\mathrm{HEPES}]=100 \mathrm{mM}, \mathrm{pH} 7.1$

Under such conditions, the arrest of Asc consumption depends on the ligand: the arrest is total with do1pa, te1pa and te2pa, quasitotal with do2pa and absent for both cyclam and cyclen. It is worth noting the Asc consumption experiments mirror the formation of ROS, in particular $\mathrm{H}_{2} \mathrm{O}_{2}$ and $\mathrm{HO}^{\circ},{ }^{[21]}$ and is a robust way to document the ability of ligand in the removal and redox silencing of $\mathrm{Cu}-\mathrm{A} \beta$ species. ${ }^{[10,22]}$ Here, we also directly monitor the formation of $\mathrm{HO}^{\circ}$ using a fluorescent assay (Figure S7) and the results perfectly match those of the Asc consumption experiment. The different behavior of the six ligands with respect to the arrest of Asc consumption may be linked to the rate of $\mathrm{Cu}^{2+}$ extraction from $\mathrm{Cu}^{2+}-\mathrm{A} \beta$ during the redox cycling. Indeed, in the course of the Asc consumption, there is a competition between $\mathrm{Cu}^{2+}-\mathrm{A} \beta$ reduction (and thus Asc consumption) and $\mathrm{Cu}^{2+}$ extraction by the ligands. If the $\mathrm{Cu}^{2+}$ extraction is not fast enough, the $\mathrm{Cu}^{2+}-\mathrm{A} \beta$ keeps on redox cycling and consuming Asc. Based on the properties of nonsubstituted and substituted ligands with respect to the rate of $\mathrm{Cu}^{2+}$ complexation, ${ }^{[13]}$ it is anticipated that the addition of methylpicolinate $\operatorname{arm}(\mathrm{s})$ accelerates $\mathrm{Cu}^{2+}$ removal from $\mathrm{A} \beta$. Such assumption has been probed by the measurements of the rate of $\mathrm{Cu}^{2+}$ binding to the six ligands without or with pre-incubation with the $A \beta$ peptide (Figure 3, panels $A-C$ and $B-D$, respectively). Several comments can be made: (i) for all the ligands, the kinetic of $\mathrm{Cu}^{2+}$ removal from $\mathrm{A} \beta$ is slower than the $\mathrm{Cu}^{2+}$ binding. This suggests that to remove $\mathrm{Cu}^{2+}$ from $\mathrm{A} \beta$, the ligand either acts on unbound $\mathrm{Cu}^{2+}$ in pre-equilibrium with peptide-bound $\mathrm{Cu}^{2+}$ or forms a ternary species with $\mathrm{Cu}^{2+}-\mathrm{A} \beta$, the creation and/or destruction of which is the rate limiting step; (ii) in line with previous reports, cyclen binds $\mathrm{Cu}^{2+}$ more rapidly than cyclam does, ${ }^{[15]}$ (iii) as anticipated, ligands with methylpicolinate arms bind $\mathrm{Cu}^{2+}$ and remove it from $\mathrm{A} \beta$ faster than the unsubstituted parent ligands and (iv) within the series of methylpicolinate ligands, the trend is as follows: do2pa < te1pa $\lesssim$ do1pa $\lesssim$ te2pa (Figure S9 for the ordering of the three later ligands). This trend is in agreement with the ability of the ligand to stop $\mathrm{Cu}^{2+}-\mathrm{A} \beta$ catalyzed ROS formation (Table 1 and Figure 2). 


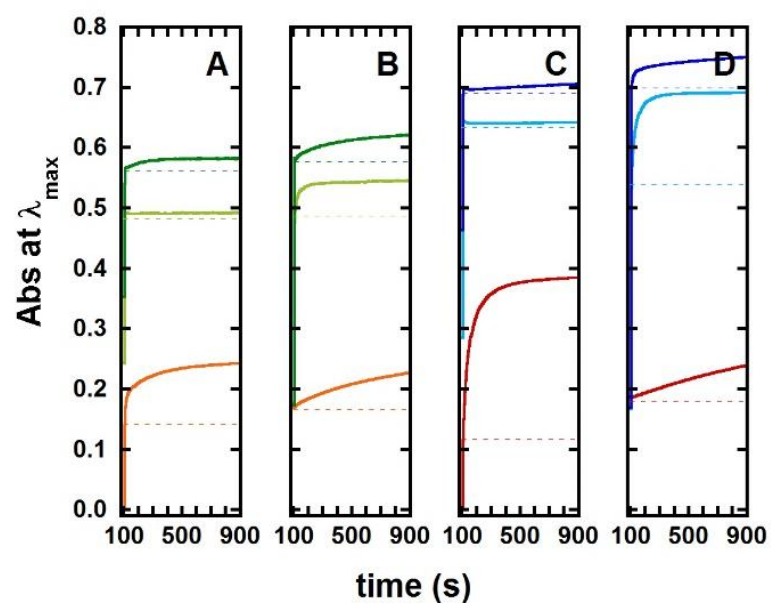

Figure 3. Kinetics of $\mathrm{Cu}^{2+}$ binding to the ligands (panels $A$ and $C$ ) and after pre-incubation with $A \beta$ (panels $B$ and $D$ ) at the wavelength of maximum intensity. Panel A: cyclen (orange), do1pa (light green) or do2pa (dark green) $+\mathrm{Cu}^{2+}$; Panel $\mathrm{B}$ : $\mathrm{Cu}^{2+}-\mathrm{A} \beta 16+\mathrm{cyclen}$ (orange), do1pa (light green) or do2pa (dark green); Panel $\mathrm{C}$ : cyclam (red), te1pa (light blue) or te2pa (dark blue) $+\mathrm{Cu}^{2+}$; Panel D: $\mathrm{Cu}^{2+}-\mathrm{A} \beta 16+$ cyclam (red), te1pa (light blue) or te2pa (dark blue). $[\mathrm{L}]=[\mathrm{A} \beta 16]=\left[\mathrm{Cu}{ }^{2+}\right]=50 \mu \mathrm{M}$, [HEPES] $=100 \mathrm{mM}, \mathrm{pH}$ 7.1. Additions are performed at $\mathrm{t}=100 \mathrm{~s}$ and absorbace at the beginning of the kinetic is showed by a thin dotted horizontal line; see Figure S8 for the corresponding whole spectra plotted as a function of time.

As modulation of $A \beta$ aggregation by $\mathrm{Cu}^{2+}$ ions could potentiate the toxicity of the $A \beta$ aggregates via the formation of other morphological structures, ${ }^{[22-23]}$ we also test the six ligands for the ability to prevent formation of $\mathrm{Cu}^{2+}$-type aggregates and to restore the formation of apo-like fibrils. All six ligands are able to do so, as evidenced by the monitoring of kinetic of fibrils formation using the classical ThT assay (Figure 4). More precisely, the formation of apo-type fibrils follows the sigmoid-type curve as expected for the nucleation - elongation - equilibrium three-step aggregation process. The $t_{1 / 2}$ value corresponding to the time at which the ThT fluorescence equals half of the maximum fluorescence, is about 20 hours. In contrast, in presence of $\mathrm{Cu}^{2+}$ ion, a weak increase of ThT fluorescence is observed in the first hours of the aggregation, followed by a stationary phase and then a sigmoid-like increase with a $t_{1 / 2}$ of about 60 hours. In presence of $\mathrm{Cu}^{2+}$, the final ThT fluorescence intensity is about twice weaker than for the apo-peptide. Upon addition of any of the six ligands, the first weak increase of ThT fluorescence is lost and a pure sigmoid-like curve recovered with $t_{1 / 2}$ values spanning from 15 to 30 hours, a divergence from the $t_{1 / 2}$ value of the apo-peptide that is in the acceptable range of error bars of aggregation experiments. The kinetic data are confirmed by TEM (Figure 5). Apo-type fibrils consists in bold intertwisted fibrils made of two to three protofilaments while the $\mathrm{Cu}^{2+}$-type fibrils are longer and thinner mainly made of one unique protofilament. In presence of te2pa on the $\mathrm{A} \beta 40+\mathrm{Cu}^{2+}$ sample, the morphology of apo-type fibrils is recovered. The identical activity of the six ligands observed here is linked to the time scale of the aggregation experiments (several hours compared to the seconds time scale of the ROS experiments), which allows $\mathrm{Cu}^{2+}$ to be removed from the $\mathrm{A} \beta$ peptide by any of them.
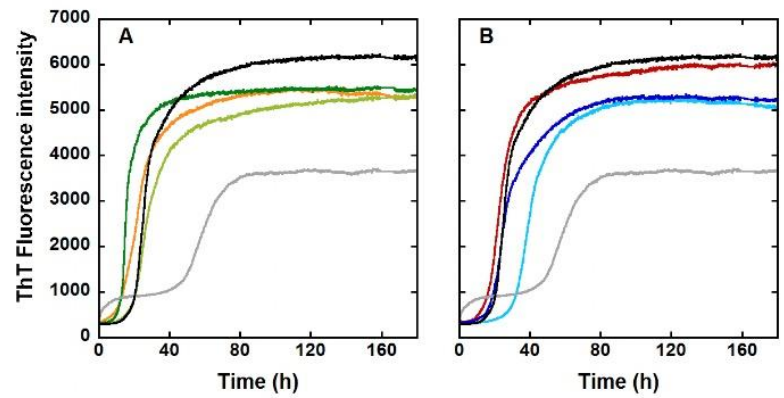

Figure 4. Aggregation curves of $A \beta$ peptide. Panel $A$. Kinetics of ThT fluorescence of $A \beta$ (black curve), $\mathrm{Cu}^{2+}-\mathrm{A} \beta$ (grey curve), $\mathrm{Cu}^{2+}$ )-A $\mathrm{A}+$ cyclen (orange curve) $\mathrm{Cu}^{2+}-\mathrm{A} \beta+$ do1 pa (light green curve), $\mathrm{Cu}^{2+}-\mathrm{A} \beta+$ do2pa (dark green curve).Panel $B$. Kinetics of ThT fluorescence of $A \beta$ (black curve), $C u^{2+}-A \beta(g r e y c u r v e), C u^{2+}$ $\mathrm{A} \beta+$ cyclam (red curve), $\mathrm{Cu}^{2+}-\mathrm{A} \beta+$ te1 pa (light blue curve), $\mathrm{Cu}^{2+}-\mathrm{A} \beta+$ te2pa (dark blue curve). $[\mathrm{L}]=[\mathrm{A} \beta 40]=20 \mu \mathrm{M},\left[\mathrm{Cu}^{2+}\right]=18 \mu \mathrm{M},[\mathrm{ThT}]=10 \mu \mathrm{M},[\mathrm{HEPES}]=$ $50 \mathrm{mM}, \mathrm{pH} 7.1, T=37^{\circ} \mathrm{C}$.

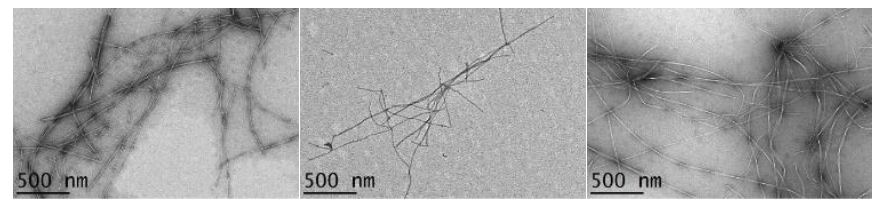

Figure 5. TEM images of $A \beta 40$ (left image), $C u^{2+}-A \beta$ (central image) and $A \beta 40+\mathrm{Cu}^{2+}+$ te2pa (right image) 


\section{Conclusions}

In the present article, we report the study of six macrocyclic ligands to demonstrate that kinetic issues are important in the design of new chelator/metallophore in the context of $A D$. The study was performed with the $A \beta$ peptide starting at position 1 , considered as the most deleterious with respect to ROS production. More recently, indeed, N-terminally truncated peptides starting at position 4 were reported to be present in significant amount in the synaptic cleft and amyloid plaques, ${ }^{[24]}$ but their $\mathrm{Cu}^{2+}$ complexes showed much more less propensity to produce ROS. ${ }^{[25]}$

Here the objective is to influence the future design of drug candidates against $A D$ and other diseases involving $\mathrm{Cu}$-induced oxidative stress, such as Parkinson disease. ${ }^{[26]}$ We show that kinetic parameters can be as important as thermodynamic or structural ones. This is particularly obvious when comparing the te2pa and the parent cyclam ligand: while the $\mathrm{Cu}^{2+}$ environments are very close in both $\mathrm{Cu}^{2+}$ complexes (the two picolinate arms are indeed very far from the $\mathrm{Cu}^{2+}$ center in the $\mathrm{Cu}^{2+}$-te2pa complex) and the affinity of the latter is higher by about 5 orders of magnitude, the te2pa can remove $\mathrm{Cu}^{2+}$ faster from $\mathrm{A} \beta$ and is active against ROS production in contrast to the parent cyclam. No general trend can be drawn within the family of azamacrocyclic ligands, since for instance in the cyclen series, the addition of a sole picolinate arm leads to a faster $\mathrm{Cu}(\mathrm{II})$ removal from $\mathrm{A} \beta$ than with the addition of two picolinate arms while in the cyclam series, this is the opposite. To draw a structure - activity relationship the series of ligands studied has to be enlarged.

More generally, having ligands able to remove copper from $A \beta$ fast enough may be one overlooked requirement to take into account in the design of drug-candidates targeting $\mathrm{Cu}$ ions to fight $\mathrm{AD}$. It adds to other better-known requirements such as being able to cross the blood brain barrier, having $\mathrm{Cu}^{2+}$ affinity higher than $\mathrm{A} \beta$, not removing $\mathrm{Cu}^{2+}$ ions from essential enzymes and being selective for $\mathrm{Cu}^{2+}$ against $\mathrm{Zn}^{2+} \cdot{ }^{[27]}$ The kinetic counterpart of the latter point, that is to say, the effect of $\mathrm{Zn}^{2+}$ ions on kinetic processes related to $\mathrm{AD}$ is currently under study and will be highlighted in further forthcoming works.

In a period where the deleterious intervention of metal ions and A peptides in $A D$ are disputed, ${ }^{[28]}$ due to the failure of the first generation of metallophores, one might wonder whether targeting copper ions is still a viable approach. With the present study, we show that an alternative way of questioning the metal hypothesis is to ask ourselves whether all requirements have been taken into account in the design of drug candidates targeting metal ions.

\section{Experimental Section}

Synthesis. Reagents were purchased from ACROS Organics and from ALDRICH Chemical Co. Cyclam was purchased from Chematech (Dijon, France). Bisformyl-Cyclam (1) ${ }^{[29]}$ and methyl 6-(chloromethyl)picolinate $(\mathbf{2})^{[30]}$ were synthesized as previously described (See Scheme S1). The solvents were freshly distilled prior to use and according to the standard methods. NMR spectra $\left({ }^{1} \mathrm{H}\right.$ and $\left.{ }^{13} \mathrm{C}\right)$ were recorded at the core facilities of the University of Brest, with Bruker Avance $500(500 \mathrm{MHz})$ or Bruker AMX-3 $300(300 \mathrm{MHz})$ spectrometers. The HR-MS analyses were performed at the Institute of Analytic and Organic Chemistry, ICOA in Orléans. Reagents, except the different ligands, were commercially available and were used as received. All the solutions were prepared in milliQ water (resistance: $18.2 \mathrm{M} \Omega . \mathrm{cm}$ ).

The $\mathrm{Cu}^{2+}$ ion source was $\mathrm{CuSO}_{4} \cdot 5 \mathrm{H}_{2} \mathrm{O}$, bought from Sigma-Aldrich.

HEPES buffer (sodium salt of 2-[4-(2-hydroxyethyl)piperazin-1-yl]ethanesulfonic acid) was bought from Sigma-Aldrich. A stock solution was prepared at $500 \mathrm{mM}, \mathrm{pH}=7.1$.

Phosphate buffer was bought from Sigma-Aldrich. Two stock solutions, $\mathrm{K}_{2} \mathrm{HPO}_{4}$ and $\mathrm{KH}_{2} \mathrm{PO}_{4}$, were prepared at 500 mM, and they were mixed until to reach a stock solution at $\mathrm{pH}=7.1$.

Sodium ascorbate was bought from Sigma-Aldrich. A stock solution was prepared at $5 \mathrm{mM}$ each day because of the quick degradation of the ascorbate.

Thioflavin T (ThT) was bought from Acros Organics. A stock solution of ThT at $250 \mu \mathrm{M}$ was prepared in water without any further purification.

Peptides. AB16 (DAEFRHDSGYEVHHQK) was bought from Genecust. A stock solution of about $10 \mathrm{mM}$ was prepared and titrated using the Tyr chromophore, with $\varepsilon=1410 \mathrm{~cm}^{-1} \mathrm{M}^{-1}$ at acidic $\mathrm{pH}$. The stock solution was stored at $4^{\circ} \mathrm{C}$. $A \beta 16$ is considered as a good model of the $A \beta 40$ with respect to metal ions binding. ${ }^{[5 a]}$ A 40 (DAEFRHDSGYEVHHQKLVFFAEDVGSNKGAlIGLMVGGVV) was bought from Genecust. Around $6 \mathrm{mg}$ were dissolved in approx. $400 \mu \mathrm{L}$ of $\mathrm{NaOH} 50 \mathrm{mM}$. This solution was purified by FPLC, with a Superdex 75 column and $\mathrm{NaOH} 15 \mathrm{mM}$ as eluent, with a flow rate at 0.9 $\mathrm{mL} \mathrm{min}$. The collected fractions were titrated using the Tyr chromophore, with $\varepsilon=2400 \mathrm{~cm}^{-1} \mathrm{M}^{-1}$ at basic $\mathrm{pH}$. The stock solution was directly used for the ThT experiments.

Single crystal X-ray diffraction measurements. Single-crystal X-ray diffraction data were collected at $170 \mathrm{~K}$ on an X-CALIBUR-2 CCD 4-circle diffractometer (Oxford Diffraction) with graphite-monochromatized MoKa radiation $(\lambda=0.71073)$. Crystal data and structure refinement details are given in Table 5. Unit-cell determination and data reduction, including interframe scaling, Lorentz, polarization, empirical absorption and detector sensitivity corrections, were carried out using attached programs of Crysalis software (Oxford Diffraction). ${ }^{[31]}$ Structures were solved by direct methods and refined by full matrix least squares method on F2 with the SHELXL ${ }^{[32]}$ suites of programs. The hydrogen atoms were identified at the last step and refined under geometrical restraints and isotropic U-constraints. ${ }^{[33]}$ CCDC number 1540075 contains the supplementary crystallographic data for this paper. These data can be obtained free of charge from the Cambridge Crystallographic Data Centre via www.ccdc.cam.ac.uk/data_request/cif.

UV-Visible spectrophotometry. UV-Vis ROS kinetic experiments were recorded on a spectrophotometer Agilent 8453 at $25^{\circ} \mathrm{C}$ in $1 \mathrm{~cm}$ path length quartz cuvette, with an $800 \mathrm{rpm}$ stirring. The samples were prepared from stock solutions of ligand, peptide and $\mathrm{Cu}^{2+}$ diluted down to 12,12 and $10 \mu \mathrm{M}$ respectively in $100 \mathrm{mM}$ HEPES solution, $\mathrm{pH}=7.1$. Ascorbate is diluted down to $100 \mu \mathrm{M}$. UV-Vis kinetic monitoring of the $\mathrm{Cu}^{2+}$ binding or $\mathrm{Cu}^{2+}$ removal from $A \beta$ by the six ligands were recorded on a spectrophotometer Agilent 8453 at $25^{\circ} \mathrm{C}$ in $1 \mathrm{~cm}$ path length quartz cuvette, with an $800 \mathrm{rpm}$ stirring. The samples were prepared from stock solutions of $\mathrm{Cu}^{2+}$, peptide and ligand diluted down to 50,50 and $50 \mu \mathrm{M}$ respectively in 100mM HEPES solution, $\mathrm{pH}=7.1$.

Fluorescence experiments. ThT experiments were recorded on a FLUOstar OPTIMA BMG LABTECH at $37^{\circ} \mathrm{C}$ in a 384 -well plate bought from Dutscher SAS. ThT was excited at $440 \mathrm{~nm}$ and the fluorescence was recorded at $490 \mathrm{~nm}$. The gain was 1200 . The samples were prepared from stock 
solutions of ligand, peptide and $\mathrm{Cu}^{2+}$ diluted down to 20,20 and $18 \mu \mathrm{M}$ respectively in $100 \mathrm{mM}$ HEPES buffer, $\mathrm{pH}=7.1$. ThT was added at a resulting concentration of $10 \mu \mathrm{M}$.

Transmission electron microscopy. Specimens were prepared for electron microscopy using the conventional negative staining procedure. $20 \mu \mathrm{L}$ of solution was absorbed on Formvar-carbon-coated grids for $2 \mathrm{~min}$, blotted, and negatively stained with uranyl acetate (1\%) for 1 min. Grids were examined with a TEM (Jeol JEM-1400, JEOL Inc, Peabody, MA, USA) at 80 kV. Images were acquired using a digital camera (Gatan Orius, Gatan Inc, Pleasanton, CA, USA) at a $\times 25000$ magnification.

Supporting information. Details of potentiometry measurements and analysis, of EPR, UV-Vis, XANES and Fluorescence spectroscopy and TEM experiments are given in the Supporting Information.

\section{Acknowledgements}

The authors acknowledge the ESRF Synchrotron, proposal CRG-FAME-BM30B 30-02-1100 for providing beam time and for their help in recording the XANES spectra.

Keywords: copper $\cdot$ peptide $\cdot$ bioinorganic $\cdot$ chelator $\cdot$ azamacrocycles

Abbreviations : $A \beta$, Amyloid- $\beta$; Abs, absorbance; $A D$, Alzheimer's disease; Asc, ascorbate; EPR: Electron Paramagnetic resonance; XANES (X-ray Absorption Near-Edge Structure) ; HEPES, 4-(2-hydroxyethyl)piperazine-1-ethanesulfonic acid; ROS, Reactive Oxygen Species ; ThT : Thioflavine T ; TEM: Transmission Electronic Microscopy.

\section{References}

${ }^{\ddagger}$ Note that in the text $A \beta$ refers to the $C$-terminally truncated $A \beta 16$ peptide regarded as an appropriate model of the full-length $A \beta$ peptide with respect to metal ions binding and/or to the full-length $A \beta 40$ peptide, unless when specific label is required for clarity purposes.

[1] A. Sanabria-Castro, I. Alvarado-Echeverría and C. Monge-Bonilla, Ann. Neurosci. 2017, 24, 46-54.

[2] a) M. G. Savelieff, S. Lee, Y. Liu and M. H. Lim, ACS Chem. Biol. 2014, 8, 856-865; b) E. Atrian-Blasco, P. Gonzalez, A. Santoro, B. Alies, P. Faller and C. Hureau, Coord. Chem. Rev. 2018, revision.

[3] K. Ono, Neurochem. Int. 2017, 17, 30331-30335.

[4] E. I. Solomon, D. E. Heppner, E. M. Johnston, J. W. Ginsbach, J. Cirera, M. Qayyum, M. T. Kieber-Emmons, C. H. Kjaergaard, R. G. Hadt and L. Tian, Chem. Rev. 2014, 114, 3659-3653.

[5] a) C. Hureau, Coord. Chem. Rev. 2012, 256, 2164-2174; b) C. Cheignon, M. Tomas, D. Bonnefont-Rousselot, P. Faller, C. Hureau and F. Collin, Redox Biology 2018, 14, 450-464.

[6] a) M. A. Santos, K. Chand and S. Chaves, Coord. Chem. Rev. 2016, 327-328, 287-303; b) K. J. Barnham and A. I. Bush, Chem. Soc. Rev. 2014, 43, 67276749; c) A. Robert, Y. Liu, M. Nguyen and B. Meunier, Acc. Chem. Res. 2015, 48, 1332-1339.

[7] E. Atrian-Blasco, A. Conte-Daban and C. Hureau, Dalton Transactions 2017, in press.

[8] a) M. E. Rice, Trends Neurosci. 2000, 23, 209-216; b) C. Cheignon, F. Collin, P. Faller and C. Hureau, Dalton Transactions 2016, 45, $12627-12631$.

[9] a) E. Atrian-Blasco, E. Cerrada, A. Conte-Daban, D. Testemale, P. Faller, M. Laguna and C. Hureau, Metallomics 2015, 7, 536-543; b) G. R. Walke, D. S. Ranade, S. N. Ramteke, S. Rapole, C. Satriano, E. Rizzarelli, G. A. Tomaselli, G. Trusso Sfrazzetto and P. P. Kulkarni, Inorg. Chem. $2017,56,3729-3732$.

[10] A. Conte-Daban, B. Boff, A. Candido Matias, C. N. Montes Aparicio, C. Gateau, C. Lebrun, G. Cerchiaro, I. Kieffer, S. Sayen, E. Guillon, C. Hureau and P. Delangle, Chem. Eur. J. 2017, 23, 17078-17088.

[11] a) T. Chen, X. Wang, Y. He, C. Zhang, Z. Wu, K. Liao, J. Wang and G. Zijian, Inorg. Chem. 2009, 48, 5801-5809; b) Y. Yang, T. Chen, S. Zhu, X. Gu, X. Jia, Y. Lu and L. Zhu, Integr. Biol. 2015, 6, 655-662.

[12] a) S. R. Banerjee, M. Pullambhatla, C. A. Foss, S. Nimmagadda, R. Ferdani, C. J. Anderson, R. C. Mease and M. G. Pomper, J. Med. Chem. 2014, 57, 26572669; b) G. J. Stasiuk and N. J. Long, Chem. Commun. 2013, 49, 2732-2746; c) E. H. Wong, G. R. Weisman, D. C. Hill, D. P. Reed, M. E. Rogers, J. S. Condon, M. A. Fagan, J. C. Calabrese, K.-C. Lam, I. A. Guzei and A. L. Rheingold, J. Am. Chem. Soc. 2000, 122, 10561-10572; d) E. Terreno, D. Delli Castelli, A. Viale and S. Aime, Chem. Rev. 2010, 110, 3019-3042.

[13] R. M. Izatt, K. Pawlak, J. S. Bradshaw and R. L. Bruening, Chem. Rev. 1995, 95, 2529-2586.

[14] a) L. Burai, I. Fábián, R. Király, E. Szilágyi and E. Brücher, J. Chem. Soc., Dalton Trans. 1998, 243-248; b) Y. H. Jang, M. Blanco, S. Dasgupta, D. A. Keire, J. E. Shively and W. A. Goddard, J. Am. Chem. Soc. 1999, 121, 6142-6151; c) J. Rohovec, P. Vojtíšek, P. Hermann, J. Ludvík and I. Lukeš, J. Chem. Soc., Dalton Trans. 2000, 0, 141-148.

[15] L. M. P. Lima, D. Esteban-Gómez, R. Delgado, C. Platas-Iglesias and R. Tripier, Inorg. Chem. 2012, 51, 6916-6927.

[16] A. Rodriguez-Rodriguez, Z. Garda, E. Ruscsak, D. Esteban-Gomez, A. de Blas, T. Rodriguez-Blas, L. M. P. Lima, M. Beyler, R. Tripier, G. Tircso and C. Platas-Iglesias, Dalton Trans. 2015, 44, 5017-5031.

[17] J. Peisach and W. E. Blumberg, Arch. Biochem. Biophys. 1974, 165, 691-708.

[18] a) R. D. Hancock, M. Salim Shaikjee, S. M. Dobson and J. C. A. Boeyens, Inorg. Chim. Acta 1988, 154, 229-238; b) M. Kodama and E. Kimura, J. Chem. Soc., Chem. Commun. 1975, 326-327.

[19] a) M. Kodama and E. Kimura, Dalton Trans. 1978, 1081-1085; b) R. J. Motekaitis, B. E. Rogers, D. E. Reichert, A. E. Martell and M. J. Welch, Inorg. Chem. 1996, 35, 3821-3827.

[20] a) R. Figueroa-Méndez and S. Rivas-Arancibia, Front. Physiol. 2015, 6, 397; b) A. Carreau, B. El Hafny-Rahbi, A. Matejuk, C. Grillon and C. Kieda, J. Cell. Mol. Med. 2011, 1239-1253.

[21] B. Alies, I. Sasaki, O. Proux, S. Sayen, E. Guillon, P. Faller and C. Hureau, Chem. Commun. 2013, 49, $1214-1216$.

[22] A. Conte-Daban, V. Ambike, R. Guillot, N. Delsuc, C. Policar and C. Hureau, Chem. Eur. J. 2018, doi: 10.1002/chem.201706049.

[23] a) J. H. Viles, Coord. Chem. Rev. 2012, 256, 2271-2284; b) P. Faller, C. Hureau and O. Berthoumieu, Inorg. Chem. 2013, 52, 12193-12206; c) M. R. Jones, E. Mathieu, C. Dyrager, S. Faissner, Z. Vaillancourt, K. J. Korshavn, M. H. Lim, A. Ramamoorthy, V. Wee Yong, S. Tsutsui, P. K. Stys and T. Storr, Chem. Sci. 2017, 8, 5636-5643; d) Y. Ji, H. J. Lee, M. Kim, G. Nam, S. J. C. Lee, J. Cho, C. M. Park and M. H. Lim, Inorg. Chem. 2017, 56, 6695-6705.

[24] V. Borghesani, B. Alies and C. Hureau, Eur. J. Inorg. Chem. 2018, 7-15.

[25] M. Mital, N. E. Wezynfeld, T. Frączyk, M. Z. Wiloch, U. E. Wawrzyniak, A. Bonna, C. Tumpach, K. J. Barnham, C. L. Haigh, W. Bal and S. C. Drew, Angew. Chem. Int. Ed. 2015, 54, 10460-10464. 
[26] E. Carboni and P. Lingor, Metallomics 2015, 7, 395-404.

[27] E. Atrian-Blasco, A. Conte-Daban and C. Hureau, Dalton Trans. 2017, 46, 12750-12759.

[28] a) E. Karran and B. De Strooper, J. Neurochem. 2016, 139, 237-252; b) S. C. Drew, Front. Neurosci. 2017, 11, 317.

[29] G. Royal, V. Dahaoui-Gindrey, S. Dahaoui, A. Tabard, R. Guilard, P. Pullumbi and C. Lecomte, Eur. J. Org. Chem. 1998, 1998, 1971-1975.

[30] M. Mato-Iglesias, A. Roca-Sabio, Z. Pálinkás, D. Esteban-Gómez, C. Platas-Iglesias, É. Tóth, A. de Blas and T. Rodríguez-Blas, Inorg. Chem. 2008, 47, 7840-7851.

[31] A. Oxford Diffraction Ltd, U.K. in Crysalis software system, version 1.171 .28 cycle 4 beta, Vol. 2005

[32] G. Sheldrick, Acta Cryst. Sect. A 2008, 64, 112-122.

[33] P. K. Glasoe and F. A. Long, J. Phys. Chem. A 1960, 64, 188-190. 